\title{
Future oriented strategy for SMEs
}

\author{
Joanna Ejdys ${ }^{\mathrm{a}, *}$ \\ ${ }^{a}$ Bialystok Technical University, Poland
}

\begin{abstract}
The main goal of the paper is to present that, using the foresight approach, small and medium size enterprises can build their innovativeness strategy. Using the literature review methods, the author compares the level of innovativeness of Polish SMEs with the level of innovativeness of other European enterprises. Showing the potential way of improving the innovativeness of SMEs by using the foresight approach, the author proposes a model of adaptation of a foresight strategy by small and medium size enterprises.

(C) 2014 The Authors. Published by Elsevier Ltd. This is an open access article under the CC BY-NC-ND license

(http://creativecommons.org/licenses/by-nc-nd/3.0/).

Peer-review under responsibility of the Kaunas University of Technology.

Keywords: Foresight; SMEs innovativeness; future oriented strategy
\end{abstract}

\section{Introduction}

Small and medium-sized enterprises with the ability to quickly and efficiently transform new ideas into successful ventures are key drivers of innovation and development of the socio-economic policies of countries. At the same time, they constitute an important channel of the flow of knowledge. The role of the SME sector in socio-economic development is indicated by basic economic indicators. In Europe, they represent $99.8 \%$ of all companies. Employment in this sector constitutes $66.7 \%$ of the total employment in Europe. The share of the sector in the creation of added value in Europe remains at the level of 58.6\% (Eurostat, 2011).

In Poland, the SME sector constitutes 99.9\% of all the market actors (Polish Agency for Enterprise Development [PARP], 2011). In the light of the CSO data, the SME businesses operating in Poland generate every second PLN of the Poland's GDP (47.6\% in 2010). The share of the SME sector in Poland in the creation of added value is about

\footnotetext{
* Corresponding author. Tel.: (+48) 784680 522; fax: (+48-85) 6631988.

E-mail address: j.ejdys@pb.edu.pl
} 
$48.4 \%$, while the number of people working in the sector constitutes $2 / 3$ of the total workforce. Compared to other EU countries, the important role of small and medium enterprises, in terms of the value of the generated GDP and jobs creation, is not consistent with the level of innovativeness in this sector.

According to the Innovation Union Scoreboard (IUS), Poland belongs to the third group - the so-called moderate innovators, occupying the 23rd place out of 27 EU countries. Polish entrepreneurs are characterized by their unbalanced potential for innovation, based mainly on human resources, with a very weak capacity for introducing innovation and R\&D cooperation. The Polish intellectual capital, as a relatively strong side, is therefore not fully used (Innovation Union Scoreboard 2012). In terms of the level of innovativeness of the SME sector, Poland occupies one of the last positions in the European Union. The results of research (European Commission, 2012) confirm that only $28 \%$ of Polish companies are undertaking any innovative activities at all, while the average for the $\mathrm{EU}$ is $52 \%$. However, taking into account the different size categories of firms, the picture of Polish innovativeness, looks quite differently. Analyzing the statistics, it can be concluded that this low innovativeness of Polish small and medium-sized businesses is among the causes of the weak Polish result in comparison to the rest of Europe. Among the 30 analyzed countries, the percentage of innovative small businesses in Poland represents $23 \%$ of all enterprises and it puts Poland in the penultimate place before Bulgaria (22\%) (Zadura-Lichota, 2013).

Research of the SME sector in Poland, carried out in 2012 by Polish Agency for Enterprise Development (PARP), indicates serious problems with elaboration and implementation of strategic development plans by that group of companies, while pointing out that, in management, short-term considerations dominate over the long-term perspective. The lack of a clear vision of the functioning and development of most of the surveyed enterprises of the SME sector is a serious threat to their development, because it does not encourage innovation efforts affecting the long-term competitiveness. Every small business faces the dilemma of reconciling short-term crisis management with the implementation of the strategy leading to continual improvement. The conditions, changing under the influence of global processes and the processes taking place inside the country, in which Polish companies operate, will progressively force the necessary adjustment measures. However, the more companies will be able to predict, and analyze the occurring changes, and in advance make any necessary strategic actions, the smoother the adjustment process will be and it will provide the desired results in the form of sustainable competitive advantages (Nieć, 2013). The ability to predict the ongoing changes and take adaptation actions in advance is particularly valuable in times of impending economic crisis.

In addition to the problems with the operation and management of business entities under the conditions of uncertainty of the business environment, the dilemma faced by a number of managers is also important $\mathrm{s}$, that is the dilemma of a multitude of information and different sources of information, forcing the selection of key and priority information. In the modern management concepts it is pointed out that "in a highly turbulent environment, seeking certain, unambiguous information, not requiring a thorough reinterpretation, is a serious methodological error" (Binsztok \& Perechuda, 2003). Relevant information is: traceable unique, difficult to interpret immediately, deriving from various sources. Only this type of information will allow managers to initiate innovative activities conditioning the achievement of competitive advantage. Also, on a macro scale, innovativeness of enterprises is a key factor in the competitiveness of the whole economy (Porter, 2006). In the area of scientific research, it seems necessary to develop appropriate tools allowing the selection of key(strategic) information of the anticipatory nature, determining the competitiveness of the enterprises and the country's economy in the long term.

According to the research conducted by PARP, in Polish small and medium-sized enterprise sector, planning future actions in a company is done spontaneously (67.7\%). In $14.9 \%$ of the surveyed enterprises there is no future action planning. $9.3 \%$ of the companies plan their actions based on a written strategy, and around $7.7 \%$ use research and analyses results commissioned to external entities (Raźniewski, 2010). The spontaneity of taking actions also determines the way of obtaining and the quality of information, which often has a selective character and a low level of usefulness. Still, a difficult challenge for the SME sector is the planning and implementation of strategic development plans, ensuring a gradual increase in innovativeness, and support for the development of intensive growth factors (knowledge, entrepreneurship, human capital).

The reasons for the current situation can be traced, among others, to the imitative paradigm of the development of companies (Bukowski, Szpor, \& Śniegocki, 2012). The GEM research shows that in Poland the rate of entrepreneurship is decisively influenced by the conditions associated with undertaking business out of necessity (European Union, 2012). The research conducted in 2013 confirms that Poland is one of the countries with a very 
unfavorable structure of entrepreneurship in terms of motivation. $41 \%$ of projects within the framework of Total Entrepreneurial Activity (TEA) are undertaken out of necessity, and only 30\% from a desire to use the opportunity. The advantage of the necessity over the opportunity occurs outside Poland only in Bosnia and Herzegovina $(20 \%$ $58 \%$ ), Macedonia (29\% - 52\%) and Russia (31\% - 36\%). This may significantly limit the potential growth of such undertaken projects. The Danes are the leaders in positive motivation of entrepreneurship (71\% - 8\%) along with the Norwegians (70\% - 7\%). The lowest share of entrepreneurship out of necessity can be found in Sweden (7\%), but there is also a lower level of entrepreneurship undertaken in order to take advantage of an opportunity (49\%) (PARP, 2013).

In the opinion of the author, the use of foresight studies by the companies of the SME sector can significantly contribute to raising the level of innovation by providing access to key strategic information ensuring a sustainable competitive advantage.

\section{Foresight method}

Due to the lack of a commonly accepted definition of the word 'foresight' in Poland, the English word is used in the literature. The closest possible meaning of the term 'foresight' may be its translation as "active building of future's image" (Jasiński, 2009). According to Keenan and Miles, foresight is a systematic participation-based process of building a medium- and long-term vision aimed at present decisions, and putting forth common actions (Keenan, \& Miles, 2001). The foresight research currently has a strong research position at the international, national and regional levels. With regard to the level of the organization, the term foresight is referred to as corporate foresight and strategic foresight. In contrast to the widespread use of foresight studies at national or regional level, in domestic and foreign literature, the use of foresight studies at the enterprise level is poorly grounded. Foresight initiatives implemented at the corporate level, described in the literature, are limited and relate mostly to projects carried out by international corporations, and to a much lesser extent to the SME sector.

The conducted research indicates that carrying out foresight projects in these enterprises may affect their innovativeness, both in terms of incremental and radical innovation.

At the same time the available results of the research conducted in Germany (Andriopoulos, \& Gotsi, 2006) regarding the expectations and experiences of German small and medium-sized enterprises in the field of foresight studies indicate that corporate foresight activities, understood as a future intelligence gathering process, are quite systematically conducted in the SME sector. Thanks to the fact that the foresight methods are relatively simple, they are used in a proper manner. The main objective of the undertaken foresight initiatives is to support strategic planning and implement product innovations. Despite the numerous examples of foresight studies in large enterprises, only a few examples apply to the SME sector. In this area three types of projects can be distinguished: (i) projects carried out for the needs of enterprises, (ii) projects with participation of the SME sector entities, (iii) projects carried out by the SME sector entities.

The first group includes foresight projects directed at the support for SMEs activities carried out, among others, by non-profit organizations such as, e.g., Syntens NT operating at the Dutch Ministry of Economic Affairs. The main goal of Syntens NT (Andriopoulos, \& Gotsi, 2006) is to promote innovation among SMEs in the Netherlands. The organization supports both the companies that already are innovative, and those, who wish to improve their innovation. Its mission includes supporting innovation processes in enterprises. To do this, the following foresight methods are used: trend analysis and, less often, scenarios. The aim of the undertaken research is increasing the awareness of the importance of "looking ahead" and the use of information in the process of improving the level of innovation in the SME sector. The second group consists of foresight projects that are not implemented by the enterprise, but the enterprises are involved in foresight projects. As an example, one can specify the design of technology foresight concerning the transport system based on fuel cells, implemented for the needs of the city of Rotterdam (Rohrbeck, \& Gemünden, 2011). The project involved a number of enterprises, perceived by the implementers of the project as crucial for improving innovation and creating demand for new technologies. The third group of foresight project is not represented in foreign literature. Only individual examples can be presented, such as consulting the firm LUNAR (Jannek, \& Burmeister, 2007) focused on the continuous improvement of innovativeness and strengthening their competitive position, which is somewhat enforced by the specificity of the 
sectors in which customers operate. Most frequently these are the sectors characterized by rapid technological change, significantly affecting the shortening of the life cycle of new products. Studies concerning foresight in Lithuania concern seeking the relationship between the use of the foresight approach and innovativeness of the SME sector. The conducted studies have been limited to manufacturing companies, with the exception of the SME service sector (Paliokaite, 2012).

\section{Results}

The main results of the conducted research allowed to identify main basic elements of foresight model dedicated to SMEs (table 1).

Table 1. Basic elements of foresight model for SMEs

\begin{tabular}{|l|l|}
\hline Elements & Foresight model for SMEs \\
\hline Main goal of foresight approach & $\begin{array}{l}\text { Building a long term strategy for innovation, not only with regard to a particular enterprise, } \\
\text { but the whole network. Foresight as a source of } \\
\text { unique, difficult to interpret information deriving from various sources }\end{array}$ \\
\hline Approach to environmental uncertainty & Concentration of key factors of change, key and strategic type of information \\
\hline Scope of foresight & $\begin{array}{l}\text { Foresight research in relation to the SME sector should focus on the dynamics of inter- } \\
\text { organizational networks, that is, the search for relationships between the network } \\
\text { participants }\end{array}$ \\
\hline Foresight focus & $\begin{array}{l}\text { Foresight project should focus less on determining the future state of technology, and more } \\
\text { on the socio-economic, inter-organizational relations (exchange of action strategies, } \\
\text { communication, interaction) }\end{array}$ \\
\hline Involvement & Social process involving the engagement of a wide group of experts \\
\hline Communication process & Process of participation, not only communication \\
\hline Responsibility & All members of the network \\
\hline Change initiation & Joining top-down and bottom-up approach \\
\hline Continuity of the process & Foresight process as a tool of continual improvement \\
\hline Level of process formalization & Acceptance for less formalized strategy building \\
\hline Final results of foresight process & Alternative scenarios, based on key factors \\
\hline Used methods & Process using more creative methods (e.g. wild cards, weak signals) \\
\hline
\end{tabular}

Source: own elaboration on basic (Ejdys, \& Kononiuk, 2013).

Foresight research, related to the level of small and medium-sized enterprises, should be of a less formal and more participatory nature, involving all the members of the network in the process of building a long-term strategy, which they are a part of. In the context of shaping the future of the organization in the turbulent, unpredictable environments foresight should be a source of unique, difficult to interpret information. The result of foresight should include the alternative development scenarios, based on the key success factors of the organization.

\section{Conclusions}

The literature review in the context of existing applications of foresight studies suggests that this tool has been used most frequently for making the socio-economic development policy of the country, regions, and far less for the needs of businesses. The applications of foresight studies, on the level of large international corporations, indicate a positive relationship between the applications of foresight studies and the level of innovation. In the context of a low level of innovation of the SME sector in Poland, it seems reasonable to develop a model of foresight studies aimed at raising the level of innovation and competitiveness of the sector. The aim of foresight studies should be building a long term strategy for innovation, not only for a particular enterprise, but the whole network. Foresight should be as a source of unique, difficult to interpret information, deriving from various sources. In the long perspective this type of information should provide a competitive advantage for small and medium-sized enterprises. Through the use of foresight studies, the organizations of this type should position their activities in the value chain of the industry, indicating clear competitive advantages in the network, which they are a part of, with the simultaneous involvement of all stakeholders. 


\section{References}

Andriopoulos, C., \& Gotsi, M. (2006). Probing the future: Mobilising foresight in multiple-product innovation firms, Futures, 8.

Binsztok, A., \& Perechuda, K. (2003). Nowe funkcje informacji we współczesnych koncepcjach zarządzania. In. R. Borowiecki, M. Kwieciński (eds.), Informacja w zarządzaniu przedsiębiorstwem: Pozyskiwanie, wykorzystanie i ochrona (Wybrane problemy teorii i praktyki). KrakówZakamycze.

Bruss, A., \& Tarnawa, A. (eds.), (2011). Raport o stanie sektora małych i średnich przedsiębiorstw w Polsce. Warszawa: PARP.

Bukowski, M., Szpor, A., \& Śniegocki A. (2012). Potencjał i bariery polskiej innowacyjności. Warszawa: Instytut Badań Strukturalnych.

Ejdys, J., \& Kononiuk, A. (2013). Doskonalenie zarządzania strategicznego poprzez wykorzystanie koncepcji badań foresightowych. Przegląd organizacji, 1, 8-13.

European Commission. (2012). Entrepreneurship in the EU and beyond, Flash Eurobarometer. Brussels.

PARP. (2011). Innowacje w sektorze usług. Warszawa.

PARP. (2013). GEM. Raport z badania Global Entrepreneurship Monitor - Polska 2012. Warszawa.

European Union. (2012). Innovation Union Scoreboard 2011. Brussels.

Jannek, K., \& Burmeister, K. (2007). Corporate Foresight in Small and Medium-Sized Enterprises, EFMN, Foresight Brief, 101.

Jasiński, L.J. (2009). Treść i przykłady badań typu foresight. Retrieved from http://www.foresight.polska2020.pl/mis/pl/publications/artykuly.

Keenan, M., \& Miles, I. (2001). A Practical Guide to Regional Foresight, Institute for Prospective Technological Studies. Seville: FOREN Network.

Eurostat. (2011). Key figures on European business with a special feature on SMEs. Luxembourg.

Nazarko, J. (ed.), \& Ejdys, J. (ed.). (2011). Metodologia i procedury badawcze w projekcie Foresight technologiczny «NT FOR Podlaskie 2020» Regionalna strategia rozwoju nanotechnologii. Białystok: Oficyna Wydawnicza Politechniki Białostockiej.

Nieć, M. (2013). Działalność innowacyjna przedsiębiorstw w Polsce na tle krajów UE. In Świat innowacyjnego społeczeństwa. Trendy na najbliższe lata, P. Zadura-Lichota (ed.). Warszawa: PARP.

Paliokaite, A. (2012). The relationship between organisational foresight and product innovation in small and medium sized enterprises. Lithuania: University of Management and Economics.

Porter, M. (2006). Przewaga konkurencyjna. Osiąganie i utrzymywanie lepszych wyników. Gliwice: Helion.

PARP. (2012). Raport o stanie sektora małych i średnich przedsiębiorstw w Polsce w latach 2010-2011. Warszawa.

Raźniewski, P. (2010). Strategia niszy rynkowej jako specyficzny element potencjału rozwojowego mikroprzedsiębiorstwa. Raport z badań. Warszawa: PARP.

Rohrbeck, R., \& Gemünden, H. G. (2011). Corporate foresight: Its three roles in enhancing the innovation capacity of a Firm. Technological Forecasting and Social Change, 78, 2231-243.

Zadura-Lichota, P. (2013). Świat innowacyjnego społeczeństwa. Trendy na najbliższe lata. Warszawa: PARP. 